\title{
Pisciglobus halotolerans gen. nov., sp. nov., isolated from fish sauce
}

\section{Correspondence \\ Somboon Tanasupawat \\ Somboon.T@chula.ac.th}

\author{
Somboon Tanasupawat, ${ }^{1}$ Jaruwan Thongsanit, ${ }^{2}$ Chitti Thawai, ${ }^{3,4}$ Keun \\ Chul Lee ${ }^{5}$ and Jung-Sook Lee ${ }^{5}$
}

\begin{abstract}
${ }^{1}$ Department of Biochemistry and Microbiology, Faculty of Pharmaceutical Sciences, Chulalongkorn University, Bangkok 10330, Thailand

${ }^{2}$ Department of Microbiology and Parasitology, Faculty of Medical Science, Naresuan University, Phisanulok 65000, Thailand

${ }^{3}$ Department of Biology, Faculty of Science, King Mongkut's Institute of Technology Ladkrabang, Bangkok 10520, Thailand

${ }^{4}$ Microbial Resource Management Unit, Scientific Instrument Center, Faculty of Science, King Mongkut's Institute of Technology Ladkrabang, Bangkok 10520, Thailand

${ }^{5}$ Korean Collection for Type Cultures (KCTC), Biological Resource Center (BRC), Korea Research Institute of Bioscience and Biotechnology (KRIBB), Yusong, Daejeon 305-806, Republic of Korea
\end{abstract}

Two strains of Gram-stain-positive, catalase-negative, tetrad-forming cocci, $\mathrm{C} 1^{\top}$ and $\mathrm{C} 02$, were isolated in Thailand from fish sauce. They were facultatively anaerobic, non-motile and non-sporeforming bacteria. These strains produced L-lactic acid from glucose. They grew at $\mathrm{pH} 5.0-9.0$, at $15-40{ }^{\circ} \mathrm{C}$ and in the presence of $10 \%(\mathrm{w} / \mathrm{v}) \mathrm{NaCl}$. The dominant fatty acid was $\mathrm{C}_{18: 1} \omega 9 \mathrm{c}$. The DNA G $+\mathrm{C}$ contents of strains $\mathrm{C} 01^{\top}$ and $\mathrm{C} 02$ were 38.6 and $38.7 \mathrm{~mol} \%$, respectively. Strain $\mathrm{C} 01^{\top}$ was related most closely to Desemzia incerta DSM $20581^{\top}$, with a $16 \mathrm{~S}$ rRNA gene sequence similarity of $96.9 \%$. The strains could be distinguished clearly from $D$. incerta DSM $20581^{\top}$ based on cell morphology, physiological and biochemical characteristics and low levels of DNA-DNA relatedness. On the basis of the data presented, strains $\mathrm{C} 01^{\top}$ and $\mathrm{CO} 2$ are considered to represent a novel species of a new genus in the Bacillus-Lactobacillus cluster, for which the name Pisciglobus halotolerans gen. nov., sp. nov. is proposed. The type strain of Pisciglobus halotolerans is $\mathrm{CO}^{\top}\left(=\mathrm{KCTC} 13150^{\top}=\mathrm{TISTR}^{\top} 1958^{\top}=\mathrm{PCU} 316^{\top}\right)$.
Gram-positive, catalase-negative cocci in the genera Aerococcus, Pediococcus, Lactococcus, Vagococcus, Enterococcus, Weissella, Oenococcus and Tetragenococcus are widely distributed in plants, beverages, fermented foods, dairy products, faeces and water (Schleifer \& Kilpper-Bälz, 1984; Schleifer et al., 1985; Collins et al., 1984, 1989, 1990, 1993; Dicks et al., 1995). Most produce L-lactic acid from glucose, except for some species in the genera Pediococcus, Weissella and Oenococcus (Collins et al., 1990; Dicks et al., 1995; Holzapfel et al., 2006). In addition, Enterococcus and Weissella strains are able to grow maximally in the presence of $10 \% \mathrm{NaCl}$, whereas halophilic Tetragenococcus strains are able to grow with over $18 \% \mathrm{NaCl}$. In the present study, we isolated Gram-stain-positive, catalase-negative and salttolerant tetrad-forming cocci from fermented fish sauce in Thailand. The strains grew maximally in the presence of

The GenBank/EMBL/DDBJ accession number for the 16S rRNA gene sequence of strain $\mathrm{CO}^{\top}{ }^{\top}$ is GU459067.

Two supplementary figures and a supplementary table are available with the online version of this paper.
$10 \%(\mathrm{w} / \mathrm{v}) \mathrm{NaCl}$ and produced L-lactic acid from glucose. On the basis of their phenotypic and chemotaxonomic characteristics, 16S rRNA gene sequence analysis and DNADNA hybridization data, they were differentiated from the closely related Desemzia incerta DSM $20581^{\mathrm{T}}$, and are considered to represent a novel species of a new genus in the Bacillus-Lactobacillus cluster.

Samples of fish mixed with salt to produce fermented fish sauce were collected from the early stage of fermentation at a factory in Chonburi Province, Thailand. Lactic acid bacteria were isolated by using a pouring-plate technique with MRS agar (De Man et al., 1960) containing $5 \% \mathrm{NaCl}$ with incubation at $30{ }^{\circ} \mathrm{C}$ for 3-5 days. Cell morphology, cell size, cell arrangement and colonial appearance were examined on MRS agar incubated for 5 days. The HuckerConn modification was used for Gram staining (Hucker \& Conn, 1923). Cell morphology and spore formation were observed by phase-contrast and scanning electron microscopy. Motility was detected by the appearance of stab cultures in soft agar (Whittenbury, 1963). Tests for catalase 
with haematin in the medium, oxidase, nitrate reduction, reaction in litmus milk (Difco), hydrolysis of L-arginine, casein, starch, gelatin and tributyrin, oxidation-fermentation, hydrogen sulfide formation and methyl red and Voges-Proskauer reactions were performed as reported by Barrow \& Feltham (1993) and Tanasupawat et al. (1992, 1998). Gas production from glucose was examined in MRS broth and a Durham tube was used for detecting gas. The effects of temperature $\left(10,40,42\right.$ and $\left.50{ }^{\circ} \mathrm{C}\right)$, starting $\mathrm{pH}$ $(4.2,5.0,6.5,8.0$ and 9.0$)$ and $\mathrm{NaCl}$ concentration $(0,10$, 15,20 and $25 \%$, w/v) were tested by using MRS broth as basal medium. Acid formation from carbohydrates was determined as reported previously (Tanasupawat et al., 1998). All tests were carried out by incubating the cultures at $30{ }^{\circ} \mathrm{C}$ for $3-5$ days, except for the investigation of effects of temperature. Additional biochemical characteristics were recorded after 2 days of incubation in API $50 \mathrm{CH}$ strips. Lactic acid was extracted from the supernatant of the GYPB fermentation broth of strains (Tanasupawat et al., 1998) by using diethyl ether and was analysed enzymically as reported by Okada et al. (1978). Analysis of total cellular fatty acids was performed with cells grown on trypticase soy agar (Difco) for $48 \mathrm{~h}$ at $30{ }^{\circ} \mathrm{C}$, by using the standard Microbial Identification System (MIDI Inc.) for automated GC analysis (Sasser, 1990). TLC plates (Merck no. 5577) developed with the solvent system n-butanol/acetic acid/ water $(60: 15: 25, \mathrm{v} / \mathrm{v})$ were used to determine lysine in the cell wall (Tanasupawat et al., 1993).

DNA was isolated from cells grown in MRS broth after incubating for 1-2 days and was purified by the method of Saito \& Miura (1963). DNA base composition was determined by reversed-phase HPLC (Tamaoka \& Komagata, 1984). The $16 \mathrm{~S}$ rRNA gene of strain $\mathrm{C} 1^{\mathrm{T}}$ was amplified and the PCR product was purified and sequenced as described previously (Tanasupawat et al., 2004). The sequence of strain $\mathrm{C}^{0} 1^{\mathrm{T}}$ was aligned with selected sequences obtained from GenBank by using CLUSTAL X version 1.83 (Thompson et al., 1997). The alignment was edited manually to remove gaps and ambiguous nucleotides prior to the construction of phylogenetic trees. Phylogenetic trees were constructed by using the neighbour-joining (Saitou \& Nei, 1987), maximum-parsimony (Kluge \& Farris, 1969) and minimum-evolution (Felsenstein, 1997) methods in the MEGA program version 2.1. Confidence values of branches of the phylogenetic tree were determined by using bootstrap analyses (Felsenstein, 1985) based on 1000 resamplings. Levels of $16 \mathrm{~S}$ rRNA gene sequence similarity were determined by using the EzTaxon server (Chun et al., 2007). Nucleotide positions are given according to the Escherichia coli numbering system (Brosius et al., 1978). DNA-DNA hybridization with photobiotin-labelled probes was carried out in $2 \times$ SSC and $50 \%$ formamide solution at $40{ }^{\circ} \mathrm{C}$ for $15 \mathrm{~h}$ (Ezaki et al., 1989).

Cells of strains $\mathrm{C} 0-1^{\mathrm{T}}$ and $\mathrm{C} 0-2$ were Gram-positive, facultatively anaerobic, non-motile, non-spore-forming cocci, $0.6-1 \mu \mathrm{m}$ in diameter, that were arranged in pairs, tetrads or packets (Fig. 1). Colonies on MRS agar plates were $0.4-1.6 \mathrm{~mm}$ in diameter, circular, raised or of low convexity with entire margins and non-pigmented. Phenotypic characteristics are detailed in the genus and species descriptions and in Table 1 . The strains were able to grow in the presence of $10 \%(\mathrm{w} / \mathrm{v}) \mathrm{NaCl}$. Cell form and colonial appearance were similar to lactic acid bacteria in the genera Pediococcus, Tetragenococcus and Aerococcus (Collins et al., 1990; Holzapfel et al., 2006). Strains C0-1 ${ }^{\mathrm{T}}$ and $\mathrm{C} 0-2$ contained $\mathrm{C}_{18: 1} \omega 9 c(39.47-43.38 \%)$ as the predominant cellular fatty acid. Their fatty acid profiles corresponded in general composition to that of $D$. incerta DSM $20581^{\mathrm{T}}$, but there were significant differences in the amounts of $\mathrm{C}_{16: 0}, \mathrm{C}_{16: 1} \omega 9 c$ and $\mathrm{C}_{18: 1} \omega 7 c$, as reported by Stackebrandt et al. (1999) and this study (Table 2). The two novel strains also contained $\mathrm{C}_{10: 0}(0.42-0.45 \%), \mathrm{C}_{12: 0}$ $(2.93-3.4 \%), \mathrm{C}_{14: 0} \quad(21.73-23.29 \%), \mathrm{C}_{16: 1} \omega 9 \mathrm{c}$ (9.94$12.03 \%), \mathrm{C}_{16: 0}(16.35-17.78 \%), \mathrm{C}_{18: 1} \omega 7 c(1.2-1.31 \%)$, $\mathrm{C}_{18: 0}(1.37-1.9 \%)$ and $\mathrm{C}_{20: 1} \omega 9 c$ (trace) (Table 2). They contained L-Lys in the cell-wall peptidoglycan. The DNA $\mathrm{G}+\mathrm{C}$ contents of strains $\mathrm{C}^{\mathrm{T}}{ }^{\mathrm{T}}$ and $\mathrm{C} 02$ were 38.6 and $38.7 \mathrm{~mol} \%$, respectively.

The almost-complete 16S rRNA gene sequence of strain $\mathrm{C}^{\mathrm{T}}{ }^{\mathrm{T}}(1501 \mathrm{nt})$ was compared against those of the type strains of all recognized species of the genus Carnobacterium, $D$. incerta and other selected representatives of the family Carnobacteriaceae. Phylogenetic analysis based on this large dataset revealed that the novel strains belonged to a cluster within the family Carnobacteriaceae (see Supplementary Figs S1 and S2, available in IJSEM Online). When the sequence of strain $\mathrm{C} 1^{\mathrm{T}}$ was compared with selected $16 \mathrm{~S}$ rRNA gene sequences of members in the family Carnobacteriaceae, it formed a clade with $D$. incerta DSM $20581^{\mathrm{T}}$ (Fig. 2). Strain $\mathrm{C} 1^{\mathrm{T}}$ shared highest levels of $16 \mathrm{~S}$ rRNA gene sequence similarity with D. incerta DSM $20581^{\mathrm{T}}(96.9 \%)$, Carnobacterium viridans MPL- $11^{\mathrm{T}}$ (95.3\%), Marinilactibacillus psychrotolerans M13-2 ${ }^{\mathrm{T}}$ (91.8\%), Isobaculum melis CCUG $37660^{\mathrm{T}}(93.9 \%)$, Granulicatella elegans ATCC $700633^{\mathrm{T}}$ (91.8\%), Atopobacter phocae $\mathrm{m} 1590 / 94 / 2^{\mathrm{T}}$ (92.4\%),

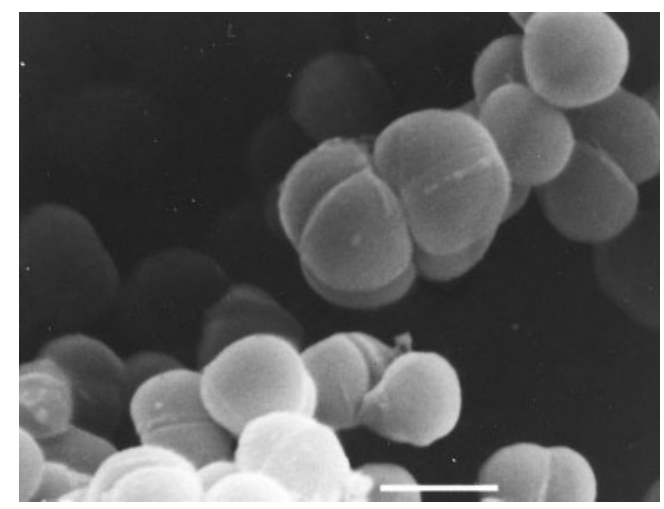

Fig. 1. Scanning electron micrograph of cells of strain $\mathrm{CO} 1^{\top}$ grown on MRS agar for 3 days. Bar, $1 \mu \mathrm{m}$. 
Table 1. Differential characteristics between strains $\mathrm{C} 01^{\top}$ and C02 and D. incerta DSM $20581^{\top}$

Strain $\mathrm{C} 02$ gave identical results to strain $\mathrm{C}_{0} 1^{\mathrm{T}}$ unless indicated. Data are from the present study except where indicated. w, Weakly positive.

\begin{tabular}{|lcc|}
\hline Characteristic & Strain $\mathbf{C 0 1}^{\mathbf{T}}$ & $\begin{array}{c}\text { D. incerta DSM } \\
\mathbf{2 0 5 8 1}^{\mathbf{T}}\end{array}$ \\
\hline Cell form & Cocci & Rods \\
Flagellation & None & One or two \\
Growth in $10 \%(\mathrm{w} / \mathrm{v}) \mathrm{NaCl}$ & + & - \\
Acid production from: & & - \\
$\quad$ D-Galactose & + & - \\
Lactose & + & - \\
Mannitol & + & $\mathrm{W}$ \\
Methyl $\alpha$-D-glucopyranoside & - & + \\
Starch & - & - \\
Turanose & $\mathrm{W}$ & $\mathrm{W}$ \\
2-Ketogluconate & - & + \\
5-Ketogluconate & - & $40^{*}$ \\
DNA G+C content (mol\%) & $38.6 / 38.7 \dagger$ & \\
\end{tabular}

${ }^{\star}$ Data from Stackebrandt et al. (1999).

$\dagger$ Values for strains $\mathrm{C} 01^{\mathrm{T}} / \mathrm{C} 02$.

Trichococcus palustris DSM $9172^{\mathrm{T}}(93.5 \%)$ and Vagococcus lutrae $\mathrm{m} 1134 / 97 / 1^{\mathrm{T}}(94.3 \%)$. The sequence of strain $\mathrm{C}_{0} 1^{\mathrm{T}}$ differed from those of its closest neighbours, the genera Desemzia (Stackebrandt et al., 1999) and Carnobacterium (Collins et al., 1987), in several signature positions (Supplementary Table S1), clearly differentiating the novel strains from both of these genera. In addition, strains $\mathrm{C}_{0} 1^{\mathrm{T}}$ and C02 showed 99.8\% DNA-DNA relatedness to each other but $\leqslant 5 \%$ to D. incerta DSM $20581^{\mathrm{T}}$.

The two novel strains could be distinguished clearly from D. incerta DSM $20581^{\mathrm{T}}$ based on cell form, physiological

Table 2. Cellular fatty acid profiles of strains $\mathrm{C}_{0} 1^{\top}$ and $\mathrm{CO} 2$ and $D$. incerta DSM $20581^{\top}$

Data were obtained in this study. Values are percentages of total fatty acids. ND, Not detected.

\begin{tabular}{|lccc|}
\hline Fatty acid & C01 $^{\mathbf{T}}$ & $\mathbf{C 0 2}$ & $\begin{array}{c}\text { D. incerta } \text { DSM } \\
\mathbf{2 0 5 8 1}^{\mathbf{T}}\end{array}$ \\
\hline $\mathrm{C}_{10: 0}$ & 0.42 & 0.45 & 0.87 \\
$\mathrm{C}_{12: 0}$ & 2.93 & 3.4 & 3.54 \\
$\mathrm{C}_{14: 0}$ & 23.29 & 21.73 & 21.67 \\
$\mathrm{C}_{16: 1} \omega 9 c$ & 12.03 & 9.94 & 28.21 \\
$\mathrm{C}_{16: 0}$ & 17.78 & 16.35 & 28.74 \\
$\mathrm{C}_{18: 1} \omega 9 c$ & 39.47 & 43.38 & 7.58 \\
$\mathrm{C}_{18: 1} \omega 7 c$ & 1.31 & 1.2 & 0.41 \\
$\mathrm{C}_{18: 0}$ & 1.37 & 1.9 & 1.37 \\
$\mathrm{C}_{20: 1} \omega 9 c$ & 0.38 & $\mathrm{ND}$ & 4.25 \\
\hline
\end{tabular}

and biochemical characteristics, cellular fatty acid compositions and DNA-DNA relatedness and 16S rRNA gene sequence data. In addition, they could be differentiated from the genera Carnobacterium, Marinilactibacillus, Isobaculum, Granulicatella, Atopobacter, Trichococcus and Vagococcus based on 16S rRNA gene sequence analyses as detailed above and as reported by Holley et al. (2002), Ishikawa et al. (2003), Lawson et al. (2000), Liu et al. (2002), Collins \& Lawson (2000) and Collins et al. (1987, 2002). Therefore, strains $\mathrm{C} 01^{\mathrm{T}}$ and $\mathrm{C} 02$ are considered to represent a novel species of a new genus of the BacillusLactobacillus cluster, for which the name Pisciglobus halotolerans gen. nov., sp. nov. is proposed.

\section{Description of Pisciglobus gen. nov.}

Pisciglobus [Pis.ci.glo'bus. L. n. piscis fish; L. masc. n. globus ball, sphere, globe; N.L. masc. n. Pisciglobus a sphere (coccus) from fish].

Cells are Gram-stain-positive, facultatively anaerobic, non-motile, non-spore-forming cocci, arranged in pairs, tetrads or packets. Colonies on MRS agar plates are circular, raised or of low convexity with entire margins and non-pigmented. Negative for catalase, gelatin hydrolysis and nitrate reduction. Ferment glucose but no gas is produced. Produce L-lactic acid from glucose. Tolerate up to $10 \%(\mathrm{w} / \mathrm{v}) \mathrm{NaCl} . \mathrm{C}_{18: 1} \omega 9 \mathrm{c}$ is the predominant fatty acid. The cell-wall peptidoglycan is of the L-Lys type. DNA G $+\mathrm{C}$ content of known strains is 38.6-38.7 mol\%. Known strains have been isolated from fermented fish sauce. The type species is Pisciglobus halotolerans.

\section{Description of Pisciglobus halotolerans sp. nov.}

Pisciglobus halotolerans (ha.lo.to'le.rans. Gr. n. hals salt; L. pres. part. tolerans tolerating; N.L. part. adj. halotolerans salt-tolerating).

Has the following characteristics in addition to those given for the genus. Cells are $0.6-1 \mu \mathrm{m}$ in diameter. Positive for methyl red reaction and hydrolysis of L-arginine. Negative for oxidase, hydrolysis of casein, starch and tributyrin, Voges-Proskauer reaction and hydrogen sulfide formation. Produces catalase in medium containing haematin. No acid, coagulation, reduction or liquefaction is observed in litmus milk. Grows at $\mathrm{pH} 5.0-9.0$, at $15-40{ }^{\circ} \mathrm{C}$ and in the presence of $10 \%(\mathrm{w} / \mathrm{v}) \mathrm{NaCl}$. Acid is produced from Damygdalin, aesculin, arbutin, D-galactose, gentiobiose (weakly), D-glucose, $\mathrm{N}$-acetylglucosamine, D-fructose, cellobiose, lactose, maltose, D-mannose, methyl $\alpha$-D-glucoside, methyl $\alpha$-D-glucopyranoside (weakly), D-mannitol, D-ribose, sucrose, salicin and trehalose, but not from adonitol, D- or L-arabinose, dulcitol, erythritol, gluconate, glycogen, glycerol, methyl $\alpha$-D-mannopyranoside, methyl $\beta$-xyloside, inositol, inulin, melibiose, melezitose, D- or L-xylose, rhamnose, D-sorbose, starch, xylitol, turanose, D-lyxose, D-tagatose, D- or L-fucose, D- or L-arabitol, 


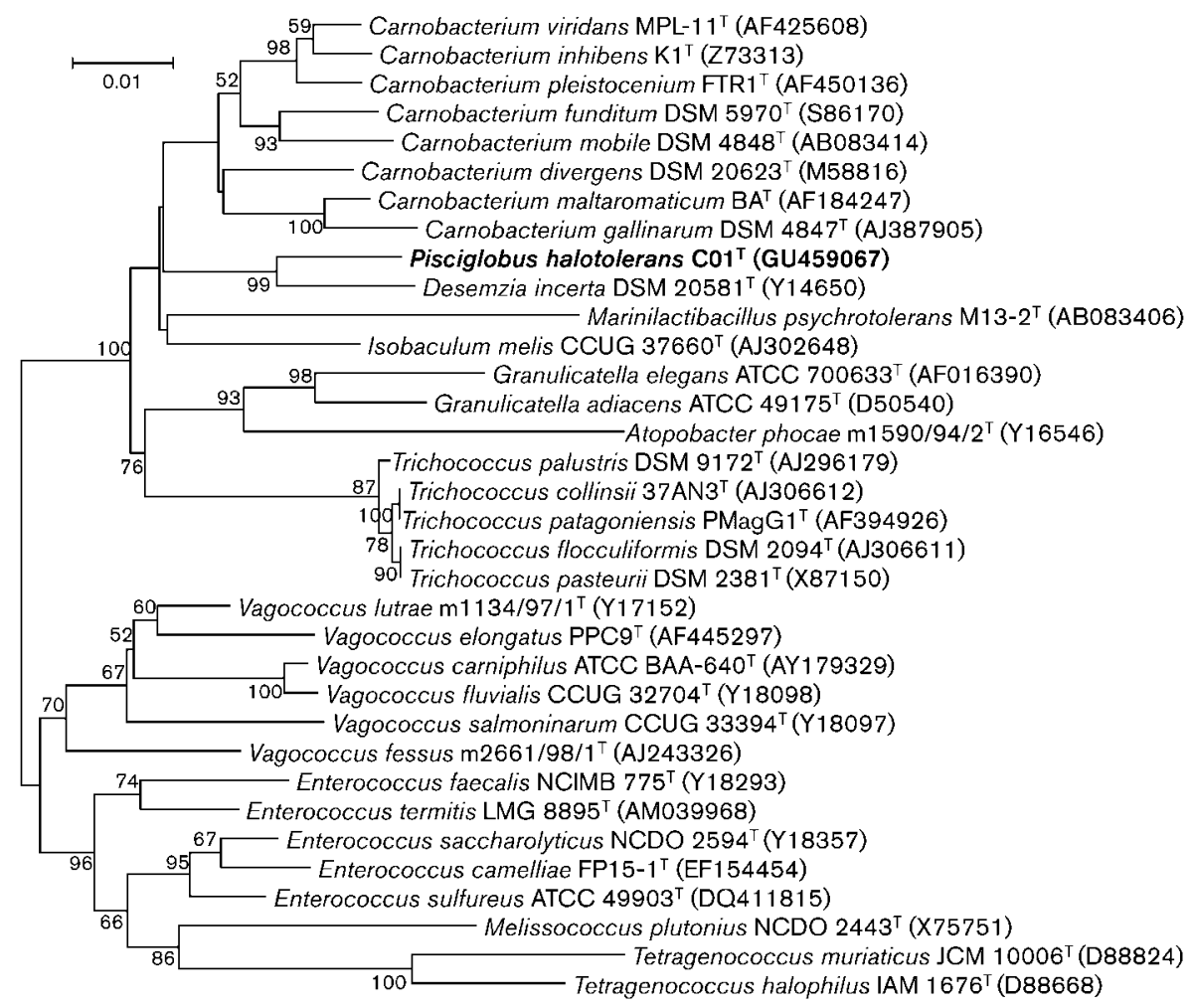

Fig. 2. Neighbour-joining tree (Saitou \& Nei, 1987) based on almost-complete 16S rRNA gene sequences showing the relationships between strain $\mathrm{C} 01^{\top}$ and the type strains of related members of the family Carnobacteriaceae. Numbers at nodes are bootstrap values (percentages of 1000 resamplings). Bar, 0.01 substitutions per nucleotide position.

2-ketogluconate, 5-ketogluconate, D-sorbitol or raffinose. The DNA G + C content of the type strain is $38.6 \mathrm{~mol} \%$.

The type strain, $\mathrm{C} 01^{\mathrm{T}}\left(=\mathrm{KCTC} 13150^{\mathrm{T}}=\right.$ TISTR $1958^{\mathrm{T}}$ $=$ PCU $316^{\mathrm{T}}$ ), was isolated from fermented fish sauce produced in Thailand. Strain C02, isolated from a similar source, is a second strain of the species.

\section{Acknowledgements}

This work was supported by the Faculty of Pharmaceutical Sciences Research Fund (1999), Chulalongkorn University, Bangkok, Thailand. We thank the director of Phichai fish sauce factory in Chonburi for providing the samples.

\section{References}

Barrow, G. I. \& Feltham, R. K. A. (editors) (1993). Cowan and Steel's Manual for the Identification of Medical Bacteria, 3rd edn. Cambridge: Cambridge University Press.

Brosius, J., Palmer, M. L., Kennedy, P. J. \& Noller, H. F. (1978). Complete nucleotide sequence of a $16 \mathrm{~S}$ ribosomal RNA gene from Escherichia coli. Proc Natl Acad Sci U S A 75, 4801-4805.

Chun, J., Lee, J.-H., Jung, Y., Kim, M., Kim, S., Kim, B. K. \& Lim, Y. W. (2007). EzTaxon: a web-based tool for the identification of prokaryotes based on $16 \mathrm{~S}$ ribosomal RNA gene sequences. Int J Syst Evol Microbiol 57, 2259-2261.
Collins, M. D. \& Lawson, P. A. (2000). The genus Abiotrophia (Kawamura et al.) is not monophyletic: proposal of Granulicatella gen. nov., Granulicatella adiacens comb. nov., Granulicatella elegans comb. nov. and Granulicatella balaenopterae comb. nov. Int J Syst Evol Microbiol 50, 365-369.

Collins, M. D., Jones, D., Farrow, J. A. E., Kilpper-Bälz, R. \& Schleifer, K. H. (1984). Enterococcus avium nom. rev., comb. nov.; $E$. casseliflavus nom. rev., comb. nov.; E. durans nom. rev., comb. nov.; E. gallinarum comb. nov.; and E. malodoratus sp. nov. Int J Syst Bacteriol 34, 220-223.

Collins, M. D., Farrow, J. A. E., Phillips, B. A., Ferusu, S. \& Jones, D. (1987). Classification of Lactobacillus divergens, Lactobacillus piscicola, and some catalase negative, asporogenous, rod-shaped bacteria from poultry in a new genus, Carnobacterium. Int J Syst Bacteriol 37, 310316.

Collins, M. D., Ash, C., Farrow, J. A. E., Wallbanks, S. \& Williams, A. M. (1989). 16S ribosomal ribonucleic acid sequence analyses of lactococci and related taxa. Description of Vagococcus fluvialis gen. nov., sp. nov. J Appl Bacteriol 67, 453-460.

Collins, M. D., Williams, A. M. \& Wallbanks, S. (1990). The phylogeny of Aerococcus and Pediococcus as determined by 16S rRNA sequence analysis: description of Tetragenococcus gen. nov. FEMS Microbiol Lett 58, 255-262.

Collins, M. D., Samelis, J., Metaxopoulos, J. \& Wallbanks, S. (1993). Taxonomic studies on some Leuconostoc-like organisms from fermented sausages: description of a new genus Weissella for the Leuconostoc paramesenteroides group of species. J Appl Bacteriol 75, 595-603. 
Collins, M. D., Hutson, R. A., Foster, G., Falsen, E. \& Weiss, N. (2002). Isobaculum melis gen. nov., sp. nov., a Carnobacterium-like organism isolated from the intestine of a badger. Int J Syst Evol Microbiol 52, 207-210.

De Man, J. C., Rogosa, M. \& Sharpe, M. E. (1960). A medium for the cultivation of lactobacilli. J Appl Bacteriol 23, 130-135.

Dicks, L. M. T., Dellaglio, F. \& Collins, M. D. (1995). Proposal to reclassify Leuconostoc oenos as Oenococcus oeni [corrig.] gen. nov., comb. nov. Int J Syst Bacteriol 45, 395-397.

Ezaki, T., Hashimoto, Y. \& Yabuuchi, E. (1989). Fluorometric deoxyribonucleic acid-deoxyribonucleic acid hybridization in microdilution wells as an alternative to membrane filter hybridization in which radioisotopes are used to determine genetic relatedness among bacterial strains. Int J Syst Bacteriol 39, 224-229.

Felsenstein, J. (1985). Confidence limits on phylogenies: an approach using the bootstrap. Evolution 39, 783-791.

Felsenstein, J. (1997). An alternating least squares approach to inferring phylogenies from pairwise distances. Syst Biol 46, 101-111.

Holley, R. A., Guan, T. Y., Peirson, M. \& Yost, C. K. (2002). Carnobacterium viridans sp. nov., an alkaliphilic, facultative anaerobe isolated from refrigerated, vacuum-packed bologna sausage. Int J Syst Evol Microbiol 52, 1881-1885.

Holzapfel, W. H., Franz, C. M. A. P., Ludwig, W., Back, W. \& Dicks, L. M. T. (2006). Genera Pediococcus and Tetragenococcus. In The Prokaryotes, 3rd edn, vol. 4, pp. 229-266. Edited by M. Dworkin, S. Falkow, E. Rosenberg, K. H. Schleifer \& E. Stackebrandt. New York: Springer.

Hucker, G. J. \& Conn, H. J. (1923). Methods of gram staining. N Y St Agric Exp Stn Tech Bull 93, 3-37.

Ishikawa, M., Nakajima, K., Yanagi, M., Yamamoto, Y. \& Yamasato, K. (2003). Marinilactibacillus psychrotolerans gen. nov., sp. nov., a halophilic and alkaliphilic marine lactic acid bacterium isolated from marine organisms in temperate and subtropical areas of Japan. Int J Syst Evol Microbiol 53, 711-720.

Kluge, A. G. \& Farris, F. S. (1969). Quantitative phyletics and the evolution of anurans. Syst Zool 18, 1-32.

Lawson, P. A., Foster, G., Falsen, E., Ohlén, M. \& Collins, M. D. (2000). Atopobacter phocae gen. nov., sp. nov., a novel bacterium isolated from common seals. Int J Syst Evol Microbiol 50, 1755-1760.

Liu, J. R., Tanner, R. S., Schumann, P., Weiss, N., McKenzie, C. A., Janssen, P. H., Seviour, E. M., Lawson, P. A., Allen, T. D. \& Seviour, R. J. (2002). Emended description of the genus Trichococcus, description of Trichococcus collinsii sp. nov., and reclassification of Lactosphaera pasteurii as Trichococcus pasteurii comb. nov. and of Ruminococcus palustris as Trichococcus palustris comb. nov. in the lowG + C Gram-positive bacteria. Int J Syst Evol Microbiol 52, 1113-1126.
Okada, S., Toyoda, T. \& Kozaki, M. (1978). An easy method for the determination of optical types of lactic acid produced by lactic acid bacteria. Agric Biol Chem 42, 1781-1783.

Saito, H. \& Miura, K. (1963). Preparation of transforming deoxyribonucleic acid by phenol treatment. Biochim Biophys Acta 72, 619-629.

Saitou, N. \& Nei, M. (1987). The neighbor-joining method: a new method for reconstructing phylogenetic trees. Mol Biol Evol 4, 406-425.

Sasser, M. (1990). Identification of bacteria by gas chromatography of cellular fatty acids, MIDI Technical Note 101. Newark, DE: MIDI Inc.

Schleifer, K. H. \& Kilpper-Bälz, R. (1984). Transfer of Streptococcus faecalis and Streptococcus faecium to the genus Enterococcus nom. rev. as Enterococcus faecalis comb. nov. and Enterococcus faecium comb. nov. Int J Syst Bacteriol 34, 31-34.

Schleifer, K. H., Kraus, J., Dvorak, C., Kilpper-Bälz, R., Collins, M. D. \& Fischer, W. (1985). Transfer of Streptococcus lactis and related streptococci to the genus Lactococcus gen. nov. Syst Appl Microbiol 6, 183-195.

Stackebrandt, E., Schumann, P., Swiderski, J. \& Weiss, N. (1999). Reclassification of Brevibacterium incertum (Breed 1953) as Desemzia incerta gen. nov., comb. nov. Int J Syst Bacteriol 49, 185-188.

Tanasupawat, S., Ezaki, T., Suzuki, K., Okada, S., Komagata, K. \& Kozaki, M. (1992). Characterization and identification of Lactobacillus pentosus and Lactobacillus plantarum strains from fermented foods in Thailand. J Gen Appl Microbiol 38, 121-134.

Tanasupawat, S., Okada, S., Suzuki, K., Kozaki, M. \& Komagata, K. (1993). Lactic acid bacteria, particularly heterofermentative lactobacilli, found in fermented foods in Thailand. Bull JFCC 9, 65-78.

Tamaoka, J. \& Komagata, K. (1984). Determination of DNA base composition by reversed-phase high-performance liquid chromatography. FEMS Microbiol Lett 25, 125-128.

Tanasupawat, S., Okada, S. \& Komagata, K. (1998). Lactic acid bacteria found in fermented fish in Thailand. J Gen Appl Microbiol 44, 193-200.

Tanasupawat, S., Thawai, C., Yukphan, P., Moonmangmee, D., Itoh, T., Adachi, O. \& Yamada, Y. (2004). Gluconobacter thailandicus sp. nov., an acetic acid bacterium in the $\alpha$-Proteobacteria. J Gen Appl Microbiol 50, 159-167.

Thompson, J. D., Gibson, T. J., Plewniak, F., Jeanmougin, F. \& Higgins, D. G. (1997). The CLUSTAL_X windows interface: flexible strategies for multiple sequence alignment aided by quality analysis tools. Nucleic Acids Res 25, 4876-4882.

Whittenbury, R. (1963). The use of soft agar in the study of condition affecting the utilization of fermentable substrates by lactic acid bacteria. J Gen Microbiol 32, 375-384. 